sciendo Порівняльна професійна педагогіка 8(3)/2018 Comparative Professional Pedagogy 8(3)/2018

DOI: $10.2478 /$ rpp-2018-0042

$\mathrm{PhD}$ in Technical Sciences, Associate Professor, OLEKSANDR IYEVLYEV

Lviv Polytechnic National University

Address: 12 S. Bandery, Lviv, 79000, Ukraine

E-mail: ievlev_lv@mail.ru

\title{
PROFESSIONAL PEDAGOGICAL MOBILITY OF EDUCATORS IN THE EUROPEAN CONTEXT
}

\begin{abstract}
The article deals with the features of promoting and organizing professional pedagogical mobility of educators in the European context. Therefore, theoretical framework of the current research includes relevant documents of the Bologna Process (the Sorbonne Declaration, the Bologna Declaration (1999), the Prague Communique (2001), The Berlin Communiqué (2003), The Bergen Communique etc.). It was specified that one of the main objectives of the Bologna process was to promote mobility of educators since it is an indispensable condition for the existence and development of the European Higher Education Area (EHEA). It was indicated that professional mobility of educators occupied a prominent place in the Bologna process, determined attractiveness and competitiveness of the EHEA worldwide and improved the quality of higher education and research. It was clarified that the following important aspects of the international dimension of teacher training and professional mobility of educators providing such training should be considered in order to improve the international mobility of teacher students: teachers of the native language for foreigners should have experience of study in the country of the language taught; it is important to encourage HEIs to recognize school work internships related to the teaching subject that were completed abroad in the framework of the study exchange programme; development of international faculties in HEIs should be encouraged. It was found that the following ways could enhance the international dimension of teacher training and support professional mobility of educators providing such training: an acknowledgement of the importance of this particular student group as well as a commitment to improving the framework conditions, such as national regulation which may hinder the mobility of teacher training students. It was concluded that professional pedagogical mobility in the European context was targeted at culminating the personality of teacher students - future educators. Based on the obtained findings, some relevant recommendations were outlined to enhance the quality of professional pedagogical mobility of future educators in Ukraine.

Keywords: mobility, mobility programme, professional pedagogical mobility, educator, teacher student, teacher training, EHEA, the Bologna Process, globalization, integration, internationalization, European context.

\section{INTRODUCTION}

The processes of globalization and internationalization inevitably place new demands, new rules, new requirements that the individual must meet in all areas of professional activity and at all levels. These essential processes influence the field of education, too. The modernization of the Ukrainian education causes the need to ensure a new quality of a modern educator, the main component of which being his/her mobility
\end{abstract}


sciendo Порівняльна професійна педагогіка 8(3)/2018

Comparative Professional Pedagogy 8(3)/2018

manifested in constant internal, personal psychological and external practical readiness for changes, rapid response to them, social and professional mobility.

Nowadays mobility is considered, on the one hand, as a factor of dynamism, increasing the intensity and variability of social processes and, on the other hand, as a factor ensuring stability and manageability of society development. Therefore, Ukrainian educational institutions need an educator who is able to master the technologies ensuring the individualization of education and the achievement of expected learning outcomes, is motivated for continuing professional development, demonstrates innovative behavior, solves complex tasks independently, manages and quickly adapts to the changing conditions.

In view of the above, it is imperative to profoundly study foreign experience, in particular European one, in promoting and organizing professional pedagogical mobility of educators since the positive aspects of such experience can be effectively implemented in Ukraine and consequently enhance the system of the national teacher education.

\section{THE AIM OF THE STUDY}

The aim of the study is to disclose the features of promoting and organizing professional pedagogical mobility of educators in the European context and outline relevant recommendations to enhance the quality of professional pedagogical mobility of future educators in Ukraine.

\section{THEORETICAL FRAMEWORK AND RESEARCH METHODS}

Theoretical framework of the current research consists of the sources, which contain some valuable information about the concept of mobility and, in particular, professional pedagogical mobility in the European content. In this regard, the official documents of the Bologna Process have been considered. They are the following: the Sorbonne Declaration (1998); the Bologna Declaration (1999); the Prague Communique (2001); The Berlin Communiqué (2003); The Bergen Communiqué (2005); the proceedings of the Bologna Process official seminar on Making Bologna a Reality: Mobility of Staff and Students (2007); the Report of the 2012-2015 BFUG working group on mobility and internationalization (2015) etc. These documents have provided a general view on the problem of professional pedagogical mobility and showed the European vision of its development and enhancement. Based on them, it has become possible to outline relevant recommendations to improve the quality of professional pedagogical mobility in Ukraine.

While researching, the following methods were used: theoretical analysis and synthesis, induction and deduction, individualization, systematization and generalization.

\section{RESULTS}

According to Yu. Klymenko (2011), the role of professional pedagogical mobility at the stage of preparing future educators is manifested at the intersection of the effects of professional pedagogical mobility and academic and virtual mobility, which ensure goalsetting (what to teach) and the very procedure (how to teach) in the education process. The concept of professional mobility for future educators is an adequate combination of its internal and external features, that is professional competency, flexibility, innovation through the participation in academic exchanges, which in turn promotes professional and personal development of these specialists

One of the main objectives of the Bologna process is to promote mobility of educators since it is an indispensable condition for the existence and development of the European Higher Education Area (EHEA). They view professional mobility of educators, scholars and managerial staff as a possibility of conducting research activities and teaching, 
as well as undergoing internships and exchanging professional experience in different countries participating in the Bologna process with respect for their rights in accordance with the law. Indeed, professional mobility of educators occupies a prominent place in the Bologna process and determines attractiveness and competitiveness of the EHEA worldwide. The promotion of professional pedagogical mobility creates opportunities for personal growth, promotes the development of the international cooperation, improves the quality of higher education and research, meets the needs of the European community and thus provides the European educational space with a professionally significant value.

The most important views on the value of mobility within the educational space are presented in the main official documents of the Bologna Process. They are the following:

1. The Sorbonne Declaration (1998) attaches special importance to creating a single European higher education area as the main way of promoting mobility, employment opportunities and overall development of the continent (Four Ministers in charge for France, Germany, Italy and the United Kingdom, 1998).

2. The Bologna Declaration (1999) states that professional mobility should be encouraged through overcoming the obstacles preventing the effective implementation of professional travels and pays particular attention to the fact that it is essential to recognize and confirm the periods spent by educators, scholars and managerial staff in the European countries other than a permanent residence or workplace for the purposes of research, teaching and advanced training and not to violate their status and legal rights (EHEA, 1999).

3. The Prague Communiqué (2001) highlights the particular importance of a social aspect of professional mobility (EHEA, 2001).

4. The Berlin Communiqué (2003) intends to prioritize professional mobility in terms of postgraduate education so that doctors of philosophy and postdoctoral researchers may be more interested in expanding a scientific cooperation in the global context and enhance research potential of future doctoral candidates (EHEA, 2003).

5. The Bergen Communiqué (2005) indicates that Ministers should focus their efforts on overcoming the obstacles to the development of mobility by encouraging participation in mobility programmes (EHEA, 2005).

The proceedings of the 2007 Bologna Process official seminar on Making Bologna a Reality: Mobility of Staff and Students organized by Education International in collaboration with ESIB (European Student Information Bureau - The National Union of Students in Europe) and UCU (The University and College Union, the UK) in London indicate that professional mobility of educators can be determined by the length of time that they should spend on business trips abroad. In this case, the following types of professional pedagogical mobility are distinguished: visits, exchanges and annual leave, grants and scholarships, temporary or permanent employment (Department for Education and Skills, 2007).

The working group on social change and mobility along with Bologna Follow-up Group (BFUG), which plays an important role in overseeing the implementation of the ministerial Communiqués as well as in developing the Bologna Process, have attempted to elaborate a common definition covering all the forms and concepts of mobility in the global context. They believe that considering the nationality as the main criterion for statistics is no longer suitable in the existing multicultural community. The BFUG group presents the following definition: professional mobility of educators refers to a period of working in the country other than a permanent residence or workplace for a specific time period (EHEA, 2015).

It must be noted that the Report of the 2012-2015 BFUG working group on mobility and internationalization (2015) prepared by the EHEA raises the problem of teacher's 
student mobility. In fact, they emphasize on the need to prioritize "teachers as multipliers and motivators for their students" since it is important to recognize the benefits of intercultural competences acquired though some personal interaction (EHEA, 2015, p. 13). They also state that despite the worldwide recognition of ERASMUS+ programmes, there still appears to be a particular problem with the proper credit transfer and certain restrictions of curricula. Therefore, it is important to discover some novel ways to facilitate "more work and study related stays abroad" (EHEA, 2015, p. 13). In addition, they pay considerable attention to the need to improve the international mobility of teacher students. In this regard, they suggest considering the following important aspects of the international dimension of teacher training and professional mobility of educators providing such training:

1) teachers of the native language for foreigners should have experience of study in the country of the language taught;

2) it is important to encourage HEIs to recognize school work internships related to the teaching subject that were completed abroad in the framework of the study exchange programme;

3) development of international faculties in HEIs should be encouraged (EHEA, 2015, p. 13).

Based on these aspects, they have outlined the following ways to enhance the international dimension of teacher training and support professional mobility of educators providing such training:

1) an acknowledgement of the importance of this particular student group as well as a commitment to improving the framework conditions, such as national regulation which may hinder the mobility of teacher training students;

2) an encouragement to higher education institutions to recognize study periods abroad and foreign qualifications in accordance with the Lisbon Recognition Convention, include mobility windows into teacher training curricula and offer joint programmes in the field of teacher training, promote exchange programmes, such as ERASMUS + offering funding for internships as a teaching assistant abroad (EHEA, 2015, pp. 27-28).

As found by Yu. Klymenko (2011), each European country is characterized by certain national differences in the implementation of professional mobility programmes for future educators, which directly depend on the activities of the institutions coordinating these programmes, as well as the statistical and text data provided by the UNESCO (United Nations Educational, Scientific and Cultural Organization), Eurostat (a statistical office of the European Communities), EURYDICE (a research network of European education systems and European educational policy).

According to the DAAD (Deutcher Akademischer Austaushdienst - German Academic Exchange Service) (2018), the countries are divided into three groups in terms of readiness for mobility programmes, which is manifested primarily in the transition to a two-tier education system:

1) the countries, where the transformation process is completed (Italy, the Netherlands, Norway, the United Kingdom);

2) the countries, where the transformation process continues (Austria, Germany, Poland and Switzerland); Spain)

3) the countries, where the transformation process has recently started (Hungary,

It must be noted that the UK is an interesting example in terms of teacher mobility, as it is widely known that the country has one of the most open and transparent recruitment 
systems in Europe. In Great Britain, higher education institutions are granted great autonomy in recruitment, where most decisions about appointments to posts are taken at the faculty level. In general, no authoritative permission is required from any higher education institution and, particularly, higher authorities (Byram, \& Dervin, 2009).

The partnership between higher education institutions and the participants of the modern labour market is considered important in ensuring the quality of professional training of future specialists and compliance with the requirements of modern employers. Such social partnerships in Ireland, France, Finland, and the UK are a common practice. However, several countries of the European Union have discovered the mechanisms for certain individual cooperation between professional education institutions and companies (Bulgaria, the Czech Republic, Lithuania, Malta, Romania). Some of them have long-standing traditions of social partnership development or are being implemented through EU funded projects (Radkevych, 2017).

Therefore, one can conclude that professional pedagogical mobility has positively affects the quality of higher education and the development of higher education institutions and consequently enhances the cultural level of the population in general. The possibility of living and studying in another country provides future educators with new and significant cultural, social and academic experience and creates opportunities for their professional and personal development. As a result, this increases their competitiveness in the international labour market and employment opportunities.

Professional pedagogical mobility plays an important role in developing and maintaining a democratic culture. Professionally mobile teacher students and teachers also contribute to the internationalization of education. Professional pedagogical mobility of modern educators is a prerequisite for teacher student mobility, as it creates atmosphere of trust and partnership between higher education institutions and is necessary for closer cooperation and recognition of study abroad. Professionally mobile teacher students and educators provide higher education institutions with new views that cause the reconsideration of the established traditions and methods. Thus, professional pedagogical mobility provides allows developing academic excellence through new contacts and attitudes, as well as comparison and development of education systems. In this open environment, it strengthens both international cooperation and interconnection, as well as enhances the quality of higher education and research. The experience of professionally mobile specialists is introduced to society and contributes to its development. The individuals who have acquired some experience of living in other countries are eager to eliminate prejudices, cultural and language barriers between people, countries and cultures.

\section{CONCLUSIONS}

Therefore, professional pedagogical mobility in the European context is targeted at culminating the personality of teacher students - future educators, since their professional and personal development directly affects the next generations, namely their students and followers. In this regard, it is extremely imperative to constantly update the ways to nurture and enhance future educators' motivation to gain valuable professional experience in the countries other than a permanent residence or workplace. As a result, they will be able to share this experience, strive for high-quality teaching, search for more effective ways of enhancing the quality of the education process.

Based on the obtained findings, the following recommendations can be outlined to enhance the quality of professional pedagogical mobility of future educators in Ukraine: 
sciendo Порівняльна професійна педагогіка 8(3)/2018

Comparative Professional Pedagogy 8(3)/2018

1) it is imperative to discover novel approaches to designing the content of mobility programmes in higher education institutions in Ukraine;

2) it is essential to establish fruitful partnerships with foreign higher education institutions, in particular European ones, since this will effectively contribute to Ukraine's higher education integration into the European Higher Education Area;

3 ) it is important to discover some effective ways to fund mobility programmes for educators from the state budget;

4) it is recommended to introduce specialized courses of study on professional pedagogical mobility so that educators may acquire all necessary information about the benefits of such experience and the possibility of choosing the most relevant internships;

5 ) it is vital to introduce additional professional benefits to the educators who regularly attend advanced professional courses, seminars or forums not only abroad but also throughout the native country.

Further studies should be aimed at disclosing the mechanisms to enhance external and internal factors in developing and strengthening the partnership between higher education institutions in European experience.

\section{REFERENCES}

1. Byram, M., \& Dervin, F. (Eds.). Students, staff and academic mobility in higher education. Newcastle, UK: Cambridge Scholars Publishing.

2. Deutcher Akademischer Austaushdienst - German Academic Exchange Service. (2018). Retrieved from https://www.daad.de/de/.

3. Department for Education and Skills. (2007). Bergen to London 2007. Secretariat Report on the Bologna Work Programme 2005-2007. Retrieved from http://www. ehea.info/media.ehea.info/file/2007_London/09/3/2007_London_BFUG-Secretariat_Report 581093.pdf.

4. EHEA. (1999). The Bologna Declaration of 19 June 1999. Joint Declaration of the European Ministers of Education. Retrieved from http://www.ehea.info/media.ehea.info/ file/Ministerial_conferences/02/8/1999_Bologna_Declaration_English_553028.pdf.

5. EHEA. (2001). Towards the European Higher Education Area. Communiqué of the meeting of European Ministers in charge of Higher Education in Prague on May $19^{\text {th }}$ 2001. Retrieved from http://www.ehea.info/media.ehea.info/file/2001_Prague/44/2/2001_ Prague_Communique_English_553442.pdf.

6. EHEA. (2003). Realising the European Higher Education Area. Communique of the Conference of Ministers responsible for Higher Education in Berlin on 19 September 2003. Retrieved from https://enqa.eu/wp-content/uploads/2013/03/BerlinCommunique1.pdf.

7. EHEA. (2005). The European Higher Education Area - Achieving the Goals. Communique of the Conference of European Ministers responsible for Higher Education, Bergen, 19-20 May 2005. Retrieved from http://www.ehea.info/media.ehea.info/file/2005_ Bergen/52/0/2005_Bergen_Communique_english_580520.pdf.

8. EHEA. (2015). Report of the $2012-2015$ BFUG working group on mobility and internationalization. Retrieved from http://bologna-yerevan2015.ehea.info/files/MI\%20WG\% 20Report.pdf.

9. Four Ministers in charge for France, Germany, Italy and the United Kingdom. (1998). Sorbonne Joint Declaration on harmonization of the architecture of the European 
sciendo Порівняльна професійна педагогіка 8(3)/2018 Comparative Professional Pedagogy 8(3)/2018

higher education system. Retrieved from http://www.ehea.info/media.ehea.info/file/1998 Sorbonne/61/2/1998_Sorbonne_Declaration_English_552612.pdf.

10. Klymenko, Yu. (2011). Profesiina mobilnist maibutnikh uchyteliv u krainakh Yevrosoiuzu. (Avtoref. dys. kand. ped. nauk). Umanskyi derzhavnyi pedahohichnyi universytet imeni Pavla Tychyny, Uman.

11. Radkevych, O. (2017). Profesiinyi rozvytok vykladachiv i treneriv zakladiv profesiinoi osvity v krainakh Yevropeiskoho Soiuzu. Naukovyi visnyk Instytutu profesiinotekhnichnoi osvity NAPN Ukrainy. Profesiina pedahohika, 13, 130-139. 